\title{
Effect of Manganese on Growth and Nodulation of Mimosa caesalpiniaefolia (Benth.)
}

\author{
Marcos G. P. de Abreu ${ }^{1}$, Paulo F. Mendes Filho ${ }^{1}$, Kaio G. V. Garcia ${ }^{1}$, José M. T. da Silva Junior ${ }^{2}$, \\ Gustavo H. da S. Albuquerque ${ }^{1}$, James M. Araujo ${ }^{3}$ \& Leonardo B. Tavella ${ }^{3}$ \\ ${ }^{1}$ Federal University of Ceará, Brazil \\ ${ }^{2}$ Maracanaú City Hall, Ceará, Brazil \\ ${ }^{3}$ Federal University of Acre, Brazil \\ Correspondence: Marcos Giovane Pedroza de Abreu, Federal University of Ceará, Ceará, Brazil. E-mail: \\ marcosabreu2009@gmail.com
}

Received: October 18, 2018

Accepted: November 20, 2018

Online Published: January 15, 2019

doi:10.5539/jas.v11n2p339

URL: https://doi.org/10.5539/jas.v11n2p339

\begin{abstract}
Soil pollution by heavy metals is mainly caused by poor management of tailings generated by mining during exploration and processing of metals. Given the concern about the soil environment, this study aimed to evaluate the tolerance and effectiveness of isolates of rhizobium strains native to soils of $\mathrm{Mn}^{2+}$-mining areas in association with Mimosa caesalpiniaefolia (Benth.) cultivated under increasing concentrations of $\mathrm{Mn}^{2+}$. Isolates of rhizobium strains, obtained from Mn-mining area, were authenticated and morphologically characterized. Effect of $\mathrm{Mn}^{2+}$ on the growth and nodulation of $M$. caesalpiniaefolia was subsequently evaluated. We obtained 14 isolates which were similar, differing only in the form of colonies. $\mathrm{Mn}^{2+}$ did not inhibit the symbiotic process between isolates and plant species. The isolates from mining area showed higher efficiency than native strains. All isolates are $\mathrm{Mn}^{2+}$-tolerant, and those from mining area can increase the tolerance of M. caesalpiniaefolia to excess $\mathrm{Mn}^{2+}$ in the soil.
\end{abstract}

Keywords: biological nitrogen fixation, heavy metal, phytoremediation

\section{Introduction}

Soil contamination by heavy metals has become a serious issue worldwide, generating risks to human health due to the entry of these toxic elements in the food chain, as well as major risk for environmental safety (Glick, 2010). Activities of mineral extraction, or mining, constitute one of the main sources of release of heavy metals in the environment. Areas degraded by this activity, compared to others such as deforestation and livestock farming, are considered as relatively small, but have a great potential to degrade the environment, especially due to the negligence in the treatment of the tailings generated in the mining process, the actual sources of contaminants, such as the heavy metals that are released in the environment and can cause serious ecological damage, affecting the quality of waters and microorganisms, as well as the soil and its microbial and faunal components, besides the plant communities (Abdu, Abdullahi, \& Abdulkadir, 2017).

Manganese (Mn) is required at low concentrations by plants and is hence considered as an important essential micronutrient for the cellular requirements of plants. It is absorbed by plants in the ionic form $\mathrm{Mn}^{2+}$ and plays an important role in the reactions of the enzymes malic dehydrogenase, oxalosuccinate decarboxylase and superoxide dismutase, being also required to break water molecules in photosystem II (Cubillas et al., 2014; Kabata-Pendias, 2011).

According to Rashed (2010), in soils with high concentrations of heavy metals, such as manganese, the toxicity caused by the metal harms the diversity of soil organisms, as well as organic matter decomposition and nitrogen mineralization. Thus, contamination of soils by these metals became an environmental problem for the world, presenting itself as a significant threat to both human health and ecological safety (Wei, Hou, ShangGuan, Li, \& $\mathrm{Li}, 2014)$. Remediation of heavy metals in mining areas is a practice necessary to protect the environment from their toxic effects and conserve ecosystems for future generations (Glick, 2010).

Sabiá (M. caesalpiniaefolia Benth) is a species native to the northeastern Brazil belonging to the family Mimosaceae. It can assume in its biological form of shrub the perenifolia tree being able to reach until 
approximately $10 \mathrm{~ms}$ of length and $30 \mathrm{~cm}$ of DAP (diameter to the height of the chest) (Carvalho, 2007). Sabiá is considered among the native species of the Northeast the most recommended and used for programs of recovery of degraded areas, for having high rates of growth and survival (P. C. F. Lima, A. Q. Lima, \& Drumond, 2003).

In an attempt to revegetate mining areas, several techniques have been sought, including phytoremediation, which is basically the use of association between plants and soil microorganisms to reduce the toxic effects of contaminants such as heavy metals or organic pollutants on the environment (Ali, Khan, \& Sajad, 2013). It is considered a rather effective, low-cost technique in the remediation of polluted soils (Baker, Ernst, Ent, Malaisse, \& Ginocchio, 2010).

According to Foy (1983), high Mn levels in plants may affect the activity of some enzymes and production of some hormones (auxin and gibberellin), as well as the proportion of amino acids and root development. Leguminous species appear to be more sensitive to high levels of $\mathrm{Mn}$, since its excess affects the number of nodules of rhizobia and consequently the efficiency of biological $\mathrm{N}_{2}$ fixation (Amara, Mohjadi, \& Miller, 1986; Dobereiner, 1966; Kabata-Pendias, 2011). Some effects of Mn toxicity on nodulating nitrogen-fixing bacteria (NNFB), according to Hungria and Araújo (1994), are mutation and effect on cell division of the bacteria, reducing their effectiveness.

Given the above, the present study aimed to evaluate the tolerance and effectiveness of isolates of strains native to soils of $\mathrm{Mn}^{+2}$-mining areas in association with sabiá (Mimosa caesalpiniaefolia Benth.) cultivated under increasing concentrations of $\mathrm{Mn}^{2+}$.

\section{Material and Methods}

\subsection{Location and Description of the Areas}

Soil samples were collected in a Mn-mining area situated in the municipality of Ocara, Ceará, Brazil. Soil samples were collected in three different areas: Area 1 (Lat.: 4³0'17.82" S; Long.: 38 31'22.89" W), considered as preserved native forest and adjacent to the mining area; Area 2 (Lat.: 4³0'14.05" S; Long.: 38 $31^{\circ} 17.65^{\prime \prime} \mathrm{W}$ ), degraded by mineral extraction; and Area 3 (Lat.: 4³0'22.36" S; Long.: 38 31'20.50" W), where the sample was collected directly from the tailings generated by the mineral extraction process.

After selecting and georeferencing the points, soil samples of approximately $30 \mathrm{~kg}$ were collected in the $0-20 \mathrm{~cm}$ layer. After collection, the soil was sieved through a $4-\mathrm{mm}$ mesh and placed in plastic bags. Soil samples were pounded to break up clods and sieved through a 2-mm mesh to obtain ADFE (Air-Dried Fine Earth) and then used for analyses of chemical and physical characteristics according to the methodologies proposed by the Brazilian Agricultural Research Corporation (EMBRAPA, 2017). The results of the analyses are presented in Table 1. 
Table 1. Chemical and physical characterization of the soils of forest area (area 1), degraded area (area 2) and tailings (area 3)

\begin{tabular}{llll}
\hline Property & Native Forest & Degraded Area & Tailings \\
\hline $\mathrm{pH}\left(1: 2.5 \mathrm{H}_{2} \mathrm{O}\right)$ & 7.03 & 5.30 & 5.03 \\
$\mathrm{~K}\left(\mathrm{mg} \mathrm{dm}^{-3}\right)$ & 12.22 & 7.04 & 6.06 \\
$\mathrm{Total} \mathrm{P}^{2}\left(\mathrm{mg} \mathrm{dm}^{-3}\right)$ & 132.57 & 24.68 & 5.80 \\
$\mathrm{Ca}^{2}\left(\mathrm{Cmol}_{\mathrm{c}} \mathrm{dm}^{-3}\right)$ & 5.7 & 2 & 2.7 \\
$\mathrm{Mg}^{2+}\left(\mathrm{Cmol}_{\mathrm{c}} \mathrm{dm}^{-3}\right)$ & 2.08 & 1.48 & 1.42 \\
$\mathrm{Al}^{3+}\left(\mathrm{Cmol}_{\mathrm{c}} \mathrm{dm}^{-3}\right)$ & 0 & 0.1 & 0.1 \\
$\mathrm{H}+\mathrm{Al}\left(\mathrm{Cmol}_{\mathrm{c}} \mathrm{dm}^{-3}\right)$ & 0.9 & 3.3 & 2.2 \\
$\mathrm{SB}\left(\mathrm{Cmol}_{\mathrm{c}} \mathrm{dm}^{-3}\right)$ & 7.8 & 3.5 & 4.1 \\
$\mathrm{CEC}\left(\mathrm{Cmol}_{\mathrm{c}} \mathrm{dm}^{-3}\right)$ & 8.7 & 6.8 & 6.3 \\
$\mathrm{~V}(\%)$ & 89.7 & 51.4 & 65.2 \\
$\mathrm{~m}(\%)$ & 0 & 2.8 & 2.4 \\
$\mathrm{OC}\left(\mathrm{g} \mathrm{kg}^{-1}\right)$ & 39.5 & 24.6 & 15.2 \\
$\mathrm{Zn}\left(\mathrm{mg} \mathrm{dm}^{-3}\right)$ & 5.23 & 1.67 & 1.17 \\
$\mathrm{Fe}\left(\mathrm{mg} \mathrm{dm}^{-3}\right)$ & 5.15 & 5.11 & 6.93 \\
$\mathrm{Mn}\left(\mathrm{mg} \mathrm{dm}^{-3}\right)$ & 332 & 421 & 516 \\
$\mathrm{Cu}\left(\mathrm{mg} \mathrm{dm}^{-3}\right)$ & 1.82 & 2.56 & 1.61 \\
$\mathrm{Sand}\left(\mathrm{g} \mathrm{kg}^{-1}\right)$ & 808.2 & 227.6 & 669.2 \\
$\mathrm{Silt}\left(\mathrm{g} \mathrm{kg}^{-1}\right)$ & 77.7 & 387.4 & 173.7 \\
$\mathrm{Clay}\left(\mathrm{g} \mathrm{kg}^{-1}\right)$ & 113.9 & 385 & 157 \\
\hline
\end{tabular}

Note. SB: sum of bases; CEC: cation exchange capacity; V (\%): base saturation; $\mathrm{m}(\%)$ : aluminum saturation.

The experiments were conducted in a greenhouse and at the Soil Microbiology Laboratory, both belonging to the Department of Soil Science (DCS) of the Federal University of Ceará (UFC), Pici Campus, in Fortaleza-CE, Brazil. According to Köppen's classification, the climate of the region is characterized as Aw' (hot tropical) with mean annual temperature and rainfall of $27^{\circ} \mathrm{C}$ and $1600 \mathrm{~mm}$, respectively, situated at the following geographic coordinates: latitude $3^{\circ} 45^{\prime} 47^{\prime \prime} \mathrm{S}$ and $38^{\circ} 31^{\prime} 23^{\prime \prime} \mathrm{W}$, with mean altitude of $47 \mathrm{~m}$.

The species Mimosa caesalpiniaefolia Benth. (Sabiá) was initially used as bait plant to catch nodulating $\mathrm{N}_{2}$-fixing bacteria (NNFB) native to the soils collected in Mn-mining areas. Then, this species was tested for symbiotic efficiency with the isolated and selected strains of NNFB, in soil with increasing levels of Mn. Sabiá seeds were purchased from the company Biosementes.

\subsection{Isolation, Authentication and Cultural Characterization of Isolates of Native Strains of NNFB From Manganese Mining Areas}

The isolation of native NNFB strains was conducted in greenhouse, using $500 \mathrm{~mL}$ plastic pots which contained soil from the three areas evaluated, sown with four seeds. The seeds used in the planting were disinfected by immersion in aqueous solution of ethanol (95\%) for 50 seconds, followed by immersion in an aqueous solution of sodium hypochlorite (5\%) for 5 minutes. After disinfection, the seeds were washed six times in sterile distilled water to remove hypochlorite residues.

Plants were daily irrigated with distilled water sterilized by autoclaving at $121{ }^{\circ} \mathrm{C}$ and 1 atm for 2 hours. Every week, $150 \mathrm{~mL}$ of the nutrient solution of Hoagland and Armon (1950), without N, were applied.

Sabiá plants were harvested 45 days after sowing to collect the most representative nodules from the root region. The collected nodules were superficially disinfected by immersion in $95 \%$ ethanol solution for 10 seconds, followed by immersion in a $10 \%$ sodium hypochlorite solution for 10 minutes, and then washed in sterilized water 5 times to remove the excess sodium hypochlorite (Dionísio et al., 2016).

Disinfected nodules were open under aseptic conditions in a laminar flow chamber using a surgical scalpel, and a sterile needle was used to extract a portion of the mass of Bacteroides from the nodule center, which showed a reddish color, characterized by the presence of leghemoglobin, typical color of nodules that are efficient at $\mathrm{N}_{2}$ fixation (Hungria \& Araujo, 1994). The drop's content was subcultured to another Petri dish containing solid 
culture medium of Vincent (1970) - YMA, with $\mathrm{pH}$ adjusted to 6.8, mixed with Congo Red dye at $1 \%$ in aqueous solution to reveal any contamination.

The plates were incubated for a period of 12 days in the absence of light in a bacterial growth chamber regulated at $28{ }^{\circ} \mathrm{C}$ until the formation of visible, light-colored colonies due to the non-absorption of Red Congo, an indication of a possible rhizobium colony without contamination. After 12 days, the light-colored colonies were subcultured to a new Petri dish containing YMA solid medium of Vincent (1970), mixed with Bromothymol blue indicator and incubated again under the same conditions.

To authenticate the isolated strains, they were inoculated again in Sabiá plants using $500-\mathrm{mL}$ plastic pots containing $400 \mathrm{~g}$ of washed sand (to remove salts), which was autoclaved for 2 hours, at pressure of $1 \mathrm{~atm}$ and temperature of $121{ }^{\circ} \mathrm{C}$. Three superficially disinfected seeds were sown in each plastic pot, with four replicates for each isolate.

Strains inoculated in the seeds were multiplied in $125-\mathrm{mL}$ Erlenmeyer flasks containing $50 \mathrm{~mL}$ of YMB culture medium of Vincent (1970), mixed with Bromothymol blue and kept under shaking until reaching a concentration of $10^{9}$ cells per $\mathrm{mL}$ of broth, quantified in Neubauer chamber. Then, $3 \mathrm{~mL}$ of the rhizobium broth were aseptically applied to the seeds at planting and five days after germination, as a follow-up application $(3 \mathrm{~mL})$ at the collar region of each recently emerged seedling. After observing the formation of nodules in the roots, the strains resulting from this authentication were again isolated and incubated to be used in the subsequent experiments.

After a 12-day period, these colonies were morphologically characterized according to Vincent (1970), based on the following parameters: reaction to Gram stain, $\mathrm{pH}$ of the medium, growth time-GT; colony color-CC; transparency-TR; mucus elevation-EL; mucus formation-MF; mucus elasticity-ME; colony form-CF.

\subsection{Effect of Manganese on Growth and Nodulation of Mimosa caesalpiniaefolia Benth.}

The experiment was conducted in a greenhouse, belonging to the Department of Soil Science of the Federal University of Ceará (UFC). Substrate consisted of a soil with low content of organic matter and low Mn concentration, to allow the evaluation of the effect of increasing doses of this metal on the development of symbiosis between nodulating $\mathrm{N}_{2}$-fixing bacteria (NNFB) and leguminous species.

The soil used was collected from the 0-20 cm layer, at the Lavoura Seca farm (Lat.: 50003'734" S; Long.: $\left.38^{\circ} 995^{\prime} 421^{\prime \prime} \mathrm{W}\right)$, situated in the municipality of Quixadá, Ceará, belonging to UFC. The soil, classified as Typic Eutrophic HAPLIC PLANOSOL, was air-dried and pounded to break up clods, then sieved through a 4-mm mesh and placed in plastic pots with capacity for $1 \mathrm{dm}^{-3}$. Samples were prepared and analyzed for physical and chemical characteristics according to the methodologies proposed by Embrapa (2017). Biological analyses were also conducted to quantify the number of viable rhizobium cells using the most probable number (MPN) technique according to Hungria and Araújo (1994) and arbuscular mycorrhizal fungi (AMF) spore density, by extracting $100 \mathrm{~g}$ of soil through wet sieving, following the procedures described by (Gerdemann \& Nicolson, 1963) (Table 2).

Table 2. Chemical, physical and biological characterization of the Typic Eutrophic HAPLIC PLANOSOL used in the experiment

\begin{tabular}{|c|c|c|c|c|c|c|c|c|c|c|}
\hline $\mathrm{pH}$ & $\mathrm{Ca}$ & $\mathrm{Mg}$ & $\mathrm{K}$ & $\mathrm{Na}$ & SB & $\mathrm{H}+\mathrm{Al}$ & $\mathrm{Al}$ & CEC & $\mathrm{V}$ & \\
\hline$\left(1: 2.5 \mathrm{H}_{2} \mathrm{O}\right)$ & \multicolumn{8}{|c|}{ 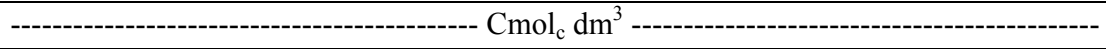 } & $\%$ & \\
\hline 4.0 & 0.6 & 0.4 & 0.12 & 0.019 & 1.1 & 1.81 & 0.15 & 2.9 & 38.6 & \\
\hline $\mathrm{P}$ & $\mathrm{OC}$ & $\mathrm{OM}$ & $\mathrm{N}$ & $\mathrm{Cu}$ & $\mathrm{Fe}$ & $\mathrm{Mn}$ & $\mathrm{Zn}$ & Sand & Silt & Clay \\
\hline \multicolumn{4}{|c|}{ 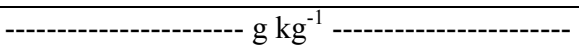 } & \multicolumn{7}{|c|}{ 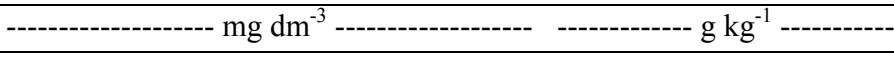 } \\
\hline 0.002 & 5.54 & 9.55 & 0.00029 & 0.18 & 5.85 & 5.3 & 1.89 & 916.0 & 62.6 & 21.4 \\
\hline MPN & & & & & & $1.950 \times$ & 5 cells & f soil & & \\
\hline AMF spore & ensity & & & & & $1883 \mathrm{sp}$ & s 100 & & & \\
\hline
\end{tabular}

Note. SB: sum of bases; CEC: cation exchange capacity; V (\%): base saturation.

According to the results of chemical analyses, the substrate was properly corrected in terms of fertility through application of $500 \mathrm{~kg} / \mathrm{ha}$ of limestone and was incubated for 30 days. After the incubation period, basal fertilization was applied using $60 \mathrm{mg}$ of $\mathrm{P}$, and $75 \mathrm{mg}$ of $\mathrm{K}$ applied as $\mathrm{KH}_{2} \mathrm{PO}_{4}, 50 \mathrm{mg}$ of S $\left(\mathrm{MgSO}_{4} \cdot 7 \mathrm{H}_{2} \mathrm{O}\right), 0.8 \mathrm{mg}$ of B $\left(\mathrm{H}_{3} \mathrm{BO}_{3}\right), 1.3 \mathrm{mg}$ of $\mathrm{Cu}\left(\mathrm{CuSO}_{4} \cdot 5 \mathrm{H}_{2} \mathrm{O}\right), 4.0 \mathrm{mg}$ of $\mathrm{Fe}(\mathrm{Fe}-\mathrm{EDTA}), 2.0 \mathrm{mg}$ of $\mathrm{Zn}\left(\mathrm{ZnSO}_{4} \cdot 7 \mathrm{H}_{2} \mathrm{O}\right)$ and $0.1 \mathrm{mg}$ of Mo 
$\left(\mathrm{H}_{2} \mathrm{MoO}_{4}\right)$ per $\mathrm{dm}^{3}$ of soil. After correction, the substrate received increasing doses of manganese (Mn), supplied in the form of Manganese Sulfate $\left(\mathrm{MnSO}_{4} \cdot \mathrm{H}_{2} \mathrm{O}\right)$. The doses used were: $0,20,40,60$ and $80 \mathrm{mg} \mathrm{dm}^{-3}$.

The arboreal leguminous species, Sabiá (M. caesalpiniaefolia), with capacity to establish efficient symbiosis with NNFB, was sown using a total of three seeds per pot, maintaining one plant after thinning. For seed inoculation, an inoculant (MIX) containing the best three isolates of isolated and authenticated strains of each area, as described previously in section 2.2 , was produced under orbital shaking of $105 \mathrm{rpm}$ at $28^{\circ} \mathrm{C}$ until the cultures reached the $\log$ phase $\left(10^{9}\right.$ cell $\left.\mathrm{mL}^{-1}\right)$. Initially, inoculation was performed by placing NNFB cells in peat using a sucrose solution $(10 \%)$ as adhesive solution and, after seedling germination, a follow-up application was made using $2.0 \mathrm{~mL} \mathrm{pot}^{-1}$ of culture in YMB (Vincent, 1970). The NNFB isolates of contaminated soil were selected based on the result of the phenotypical evaluation of nodulation (Table 3 ).

Table 3. Phenotypical characterization of the nodulation of Sabiá (Mimosa caesalpiniaefolia Benth.) by NNFB isolates from the manganese mining area

\begin{tabular}{llllllll}
\hline Isolates & Origin & $\begin{array}{l}\text { Plant height } \\
(\mathrm{cm})\end{array}$ & Shoot color & $\begin{array}{l}\text { Position of nodules } \\
\text { in the root }\end{array}$ & $\begin{array}{l}\text { Nodule form } \\
\text { and surface }\end{array}$ & $\begin{array}{l}\text { Nodule frequency } \\
\text { center color }\end{array}$ \\
\hline SAI1 & FOREST & 11.90 & IG & Main root & FL/R & HN & Intense \\
SAI2 & FOREST & 8.47 & LG & Main root & FL/R & HN & Intense \\
SAI5 & FOREST & 9.77 & LG & Lateral roots & FL/R & F & Intense \\
SAI8 & DA & 13.83 & IG & Main root & FL/R & HN & Intense \\
SAI9 & DA & 11.73 & IG & Main root & FL/R & HN & Intense \\
SAI10 & DA & 10.13 & LG & Lateral roots & FL/R & F & Medium \\
SAI11 & TAILINGS & 9.67 & LG & Main root & FL/R & HN & Intense \\
SAI13 & TAILINGS & 10.00 & IG & Main root & FL/R & HN & Intense \\
SAI14 & TAILINGS & 11.03 & IG & Main root & FL/R & HN & Intense \\
\hline
\end{tabular}

Note. DA: degraded area; IG: intense green; LG: light green; FL/R: finger-like and rough; HN: highly numerous; F: few.

Sabiá plants were harvested 60 days after sowing, when the following variables were analyzed: number of nodules $(\mathrm{NN})$; nodule dry matter (NDM); shoot dry matter (SDM); nitrogen content in the shoots, determined by the micro-Kjeldahl method (Tedesco, Bohnem, Gianello, Bissani, \& Volkweiss, 1995); manganese content in the shoots, in an extract obtained from nitric-perchloric digestion (Silva, 2009), determined by spectrophotometry of atomic absorption; and nitrogen accumulation in the shoots (NAS). $\mathrm{N}$ accumulation in the shoots was calculated by multiplying shoot dry matter by the $\mathrm{N}$ content.

The experimental design used was completely randomized, in a $5 \times 4$ factorial arrangement, considering: i) five doses of $\mathrm{Mn}\left(0 ; 20 ; 40 ; 60\right.$ and $\left.80 \mathrm{mg} \mathrm{dm}^{-3}\right)$; ii) four treatments of inoculation (control-not inoculated; MIX area 1 ; MIX area 2 and MIX area 3), with four replicates, totaling 80 experimental plots.

The obtained data were subjected to analysis of variance. When significant difference was observed, qualitative data were compared by Tukey test $(p<0.05)$, while quantitative data (doses) were subjected to regression analysis, using the statistical program SISVAR (Ferreira, 2011).

\section{Results and Discussion}

\subsection{Isolation, Authentication and Cultural Characterization of Isolates of Native Strains of NNFB From Manganese Mining Area}

The leguminous species used as bait plant, sabiá, was able to nodulate with the strains native to the different soils collected in the $\mathrm{Mn}^{2+}$-mining area, which demonstrates compatibility between macro and microsymbionts in the three situations evaluated (native forest area, degraded area and tailings). After authentication of the selected isolates, 14 isolates of NNFB strains were obtained, 5 of which from the preserved forest area, 4 from the area degraded by mineral extraction and 5 from the tailings (Table 4). 
Table 4. NNFB from the manganese mining area authenticated in association with sabiá (Mimosa caesalpiniaefolia Benth.)

\begin{tabular}{lll}
\hline Isolates & Host & Origin \\
\hline SAI1 & Sabiá & Forest area \\
SAI2 & Sabiá & Forest area \\
SAI3 & Sabiá & Forest area \\
SAI4 & Sabiá & Forest area \\
SAI5 & Sabiá & Forest area \\
SAI7 & Sabiá & Degraded area \\
SAI8 & Sabiá & Degraded area \\
SAI9 & Sabiá & Degraded area \\
SAI10 & Sabiá & Degraded area \\
SAI11 & Sabiá & Tailings \\
SAI12 & Sabiá & Tailings \\
SAI13 & Sabiá & Tailings \\
SAI14 & Sabiá & Tailings \\
SAI15 & Sabiá & Tailings \\
\hline
\end{tabular}

In the authentication process, it was observed that out of all isolates of the selected strains, in a total of 15 , only 1 was negative, while the remaining 14 (Table 4) were able to establish an efficient symbiotic relationship with the host, characterized by the intense green color of the leaves and intense red color of nodule center, indicating high concentration of leghemoglobin, and consequently good efficiency in $\mathrm{N}_{2}$ fixation.

Soils contaminated by heavy metals usually have conditions of low fertility and become highly stressing environments for the biological community (Abdu et al., 2017). Thus, studies on the obtaining of NNFB adapted to such conditions become very important for successful programs of revegetation of soils contaminated by metals. Several authors have reported the growth capacity of these microorganisms in the presence of heavy metals (Matsuda, Moreira, \& Siqueira, 2002; Rangel et al., 2017; Trannin, Moreira, \& Siqueira, 2001; Trannin, Moreira, Siqueira, \& Lima, 2001), as well as isolation of NNFB from areas contaminated by heavy metals (Aafi et al., 2015; Castro et al., 2017; Grison, Jackson, Merlot, Dobson, \& Grison, 2015; Nonnoi et al., 2012).

It is worth pointing out that there is no vegetation in the area degraded by mining and in the generated tailings, so that the NNFB present in these environments survive without the direct influence of this environmental component, besides other conditions of high stress such as low availability of organic matter, $\mathrm{P}$ and $\mathrm{K}$, slightly acid $\mathrm{pH}$ and high Mn concentration, which may indicate a high capacity of survival and tolerance of these bacteria, especially to the presence of high Mn concentrations. Some mechanisms used by these microorganisms in the tolerance to heavy metals have already been identified, particularly the production of exopolysaccharides (Nocelli, Bogino, Banchio, \& Giordano, 2016), production of siderophores (Schalk, Hannauer, \& Braud, 2011) and efflux of excess metals (Cubillas et al., 2014).

The cultural and morphological characterization of the isolates of strains authenticated and selected for the essay on the effect of Mn on the growth and nodulation of sabiá (Table 3) is presented in Table 5. It can be noted that all isolates showed Gram negative reaction, which is characteristic of the NNFB group belonging to proteobacteria (Brenner, Krieg, \& Staley, 2005). 
Table 5. Cultural characteristics of isolates of NNFB strains from $\mathrm{Mn}^{2+}$-mining area in association with sabiá (Mimosa caesalpiniaefolia Benth.)

\begin{tabular}{lllllllllll}
\hline Isolates & Origin & Gram & pH of the medium & GT & CC & TR & EL & MF & ME & CF \\
\hline SAI1 & Forest & N & A & F & W & O & C & P & V & Circ. \\
SAI2 & Forest & N & A & F & W & O & C & P & V & DL. \\
SAI5 & Forest & N & A & F & W & O & C & P & V & Irr. \\
SAI8 & DA & N & A & F & W & O & C & P & V & Irr. \\
SAI9 & DA & N & A & F & W & O & C & P & V & Irr. \\
SAI10 & DA & N & A & F & W & O & C & P & V & DL. \\
SAI11 & Tailings & N & A & F & W & O & C & P & V & Circ. \\
SAI13 & Tailings & N & A & F & W & O & C & P & V & Circ. \\
SAI14 & Tailings & N & A & F & W & O & C & P & V & Circ. \\
\hline
\end{tabular}

Note. DA: degraded area; N: negative; A: acid; GT: growth time; F: fast; CC: colony color; W: white; TR: transparency; O: opaque; EL: mucus elevation; C: convex; MF: mucus formation; P: present; ME: mucus elasticity; V: viscous; CF: colony form; Circ: Circular; DL: Dot-like; Irr: irregular.

Regarding the change in culture medium $\mathrm{pH}$, the nine isolates selected were able to acidify the culture medium. For the growth time, all showed fast growth (3 days) in YMA culture medium mixed with Bromothymol blue. Fast growth capacity is already well documented and is typical of strains from arid and semi-arid climates, where the ability to fix $\mathrm{N}_{2}$ is not the most important aspect for these microorganisms, but in fact their survival (Sprent, 1994). This characteristic also brings advantages in the competition with other microorganisms in the rhizosphere (Martins, Neves, \& Rumjanek, 1997).

As observed, the isolates were similar, sharing the same characteristics with respect to several parameters, showing differences only in colony form. Possibly these isolates may belong to the same species, since they had similar characteristics, but it is not possible to state clearly because no molecular techniques were used for a definitive position in terms of taxonomy of these bacteria. In species belonging to the subfamily Mimosaceae (Mimosa), researchers have recently discovered that they can be nodulated mainly by species from the group of $\beta$-rizhobia (Burkholderia, Cupriavidus) (Bontemps et al., 2010; Chen et al., 2003), similarly to what occurs with sabiá (M. caesalpiniifolia) (Chen et al., 2008a; Martins et al., 2015).

\subsection{Effect of Manganese on the Growth and Nodulation of Mimosa caesalpiniaefolia Benth.}

The analysis of variance for the studied variables of $M$. caesalpiniaefolia is presented in Table 6, corresponding to the values of probability and significance of $\mathrm{F}$ test for the main effects of treatments and their interactions. The interaction between Mn doses and NNFB inoculation treatments was significant for number of nodules (NN), nodule dry matter (NDM), shoot dry matter (SDM) and manganese content in the shoots (Mn), whereas the nitrogen content $(\mathrm{N})$ and accumulation (NAS) were significantly affected only by the factor NNFB.

Table 6. Summary of analysis of variance for number of nodules (NN), nodule dry matter (NDM), shoot dry matter $(\mathrm{SDM})$, nitrogen content $(\mathrm{N})$, nitrogen accumulation in the shoots (NAS) and manganese content in the shoots (Mn) for treatment factors and their interactions on sabiá (Mimosa caesalpiniaefolia Benth.)

\begin{tabular}{llllllll}
\hline \multirow{2}{*}{ S.V. } & \multirow{2}{*}{ D.F. } & \multicolumn{5}{c}{ Mean Square } \\
\cline { 3 - 7 } & & $\mathrm{NN}$ & $\mathrm{NDM}$ & $\mathrm{SDM}$ & $\mathrm{N}$ & $\mathrm{NAS}$ & Mn \\
\hline DOSE (A) & 4 & $146.63^{* *}$ & $344.98^{* *}$ & $0.348^{* *}$ & $22.97^{\text {ns }}$ & $208.08^{\text {ns }}$ & $52.60^{* *}$ \\
NNFB (B) & 3 & $2048.54^{* *}$ & $1291.37^{* *}$ & $0.53^{* *}$ & $249.84^{* *}$ & $1390.73^{* *}$ & $65.21^{* *}$ \\
Int. (A x B) & 12 & $166.17^{* *}$ & $1048.36^{* *}$ & $0.387^{* *}$ & $13.29^{\text {ns }}$ & $200.63^{\text {ns }}$ & $103.80^{* *}$ \\
C.V. \% & & 33.51 & 11.52 & 16.39 & 15.14 & 35.98 & 24.8 \\
\hline
\end{tabular}

Note. S.V.: Sources of variation; D.F.: degrees of freedom; (A): Mn doses; (B): treatments of inoculation with nodulating nitrogen-fixing bacteria; C.V.: coefficient of variation; ${ }^{* *}, *$, ns: significant at $0.01,0.05$ probability levels and not significant by $\mathrm{F}$ test, respectively. 
The variables number of nodule and nodule dry matter varied as a function of the interaction between Mn doses and NNFB, but no linear or quadratic fit could explain them, therefore, adjustments were made to the models most appropriate to the behavior of the data.

All inoculation treatments were able to establish effective symbiosis and form nodules with the microsymbiont, even in the presence of Mn. The strains of the control treatment had the lowest number of nodules compared to the isolates from mining area inoculated. The mix forest area showed higher number of nodules, with 39.00 and 31.75 nodules plant ${ }^{-1}$ at doses of 20 and $80 \mathrm{mg} \mathrm{dm}^{-3}$, respectively. The mix degraded area, although there was no significant statistical difference between doses, reduced the number of nodules with increasing doses of Mn, demonstrating sensitivity to the presence of the metal. The mix tailings showed slight sensitivity to the presence of Mn only at dose of $20 \mathrm{mg} \mathrm{dm}^{-3}$, statistically differing from the other treatments. The other doses did not cause effect on the isolates in terms of formation of nodules with the microsymbiont (Figure 1).

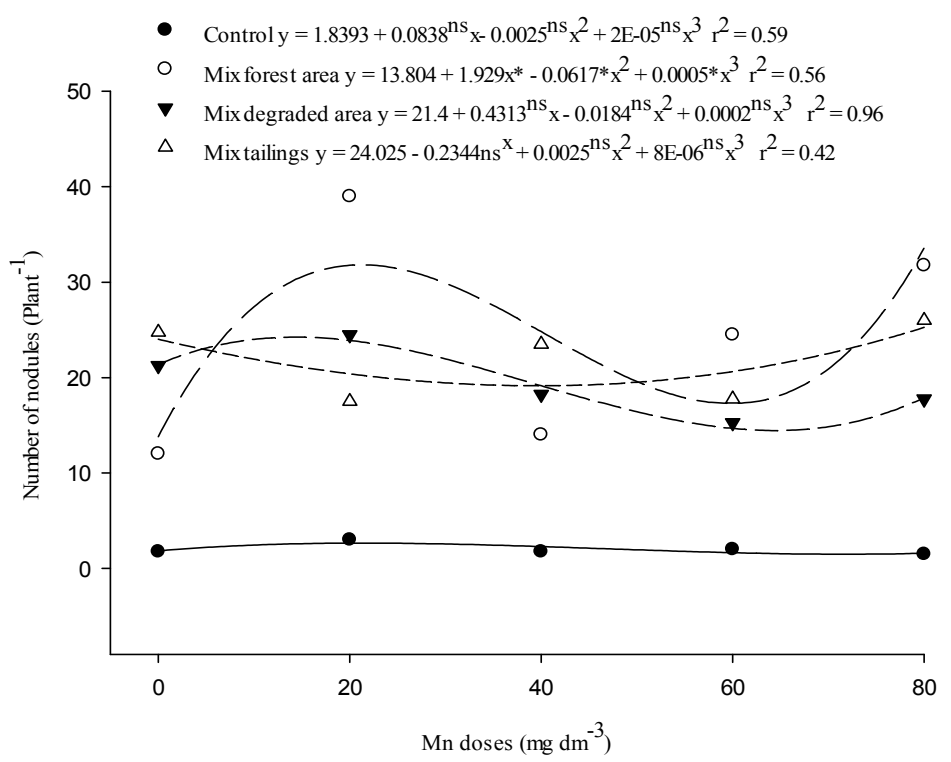

Figure 1. Number of nodule (NN) of sabiá (Mimosa caesalpiniaefolia Benth.) subjected to Mn doses and treatments of inoculation with rhizobia

For nodule dry matter, the control treatment in the absence of Mn showed highest production (51.15 mg plant $\left.{ }^{-1}\right)$ differing only from the mix forest area. In the presence of Mn, there was a reduction in NDM, but at Mn doses of 40 and $60 \mathrm{mg} \mathrm{dm}^{-3}$ the values were equal or superior to those of the isolates from mining area. The mix forest area showed the highest NDM values in the presence of Mn at doses of 20,60 and $80 \mathrm{mg} \mathrm{dm}^{-3}$, statistically differing from the other treatments. In the absence of $\mathrm{Mn}$ and at dose of $40 \mathrm{mg} \mathrm{dm}^{-3}$, there were lower NDM values, a reflex of lower production of nodules. The isolates of the mix degraded area and mix tailings were statistically equal in terms of NDM production (Figure 2). 


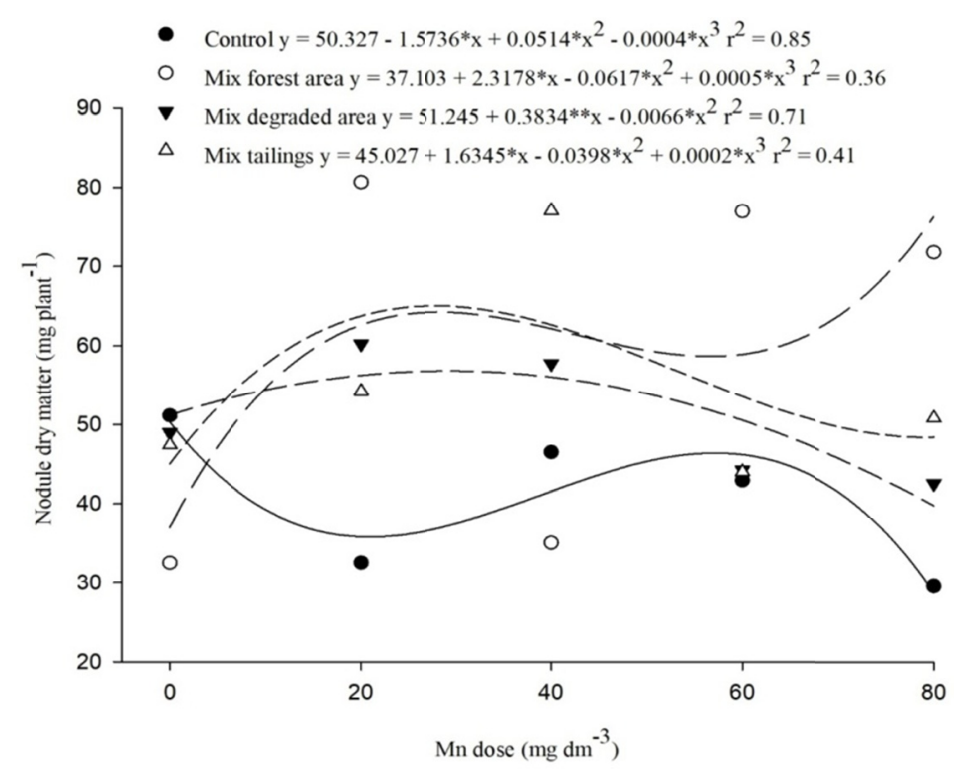

Figure 2. Nodule dry matter (NDM) of sabiá (Mimosa caesalpiniaefolia Benth.) subjected to Mn doses and treatments of inoculation with rhizobia

As observed in the results, the Mn doses used in the present study had no major effect on the symbiotic relationship between macro and microsymbionts, especially on the formation of nodules and dry matter production. The lower number of nodules formed in the control treatment (native community) may be explained by the fact that there is a small community of rhizobia present in the soil capable of establishing symbiosis with sabiá. However, despite the lower number of nodules, these strains were able to equal the isolates from mining area in terms of NDM production, demonstrating a "compensation" effect, i.e., increase in the size of nodules (Castro et al., 2017; Dobereiner, 1966).

The isolates of Mn-mining area (mix forest area, mix degraded area and mix tailings) were tolerant to the presence of the heavy metal in the soil, which is also confirmed by Franco and Döbereiner (1971). These authors state that the formation of nodules is an indication that the initial mechanisms of nodulation were not fully affected and it may indicate tolerance of the rhizobium strain to the presence of $\mathrm{Mn}$ at higher concentrations.

The number and dry matter of nodules were positively correlated with the dry matter of plant shoots $(\mathrm{r}=0.50 ; \mathrm{p} \leq$ $0.01 ; \mathrm{r}=0.49 ; \mathrm{p} \leq 0.01)$, respectively. These parameters were also positively correlated with the nitrogen content $(\mathrm{r}$ $=0.76 ; \mathrm{p} \leq 0.01 ; \mathrm{r}=0.55 ; \mathrm{p} \leq 0.01)$, respectively, demonstrating high potential for plant growth promotion. In this case, the number of nodules would be an important parameter for the selection of strains (Dobereiner, 1966).

The data referring to shoot dry matter production promoted by strains native to the soil (control) fitted to a linear regression model, which indicated a reduction in shoot dry matter with increasing doses of $\mathrm{Mn}$, reaching $43.2 \%$ at the dose of $60 \mathrm{mg} \mathrm{dm}^{-3}$ compared to the dose 0 . The mix forest area fitted to a quadratic regression model and, as Mn doses increased, there was an increment in shoot dry matter production, reaching $88.3 \%$ at the dose of $80 \mathrm{mg}$ $\mathrm{dm}^{-3}$. The data of the mix degraded area fitted to a linear model and shoot dry matter production increased with the increment in Mn doses, with highest increment (40.2\%) observed at dose of $60 \mathrm{mg} \mathrm{dm}^{-3}$ (Figure 3). 


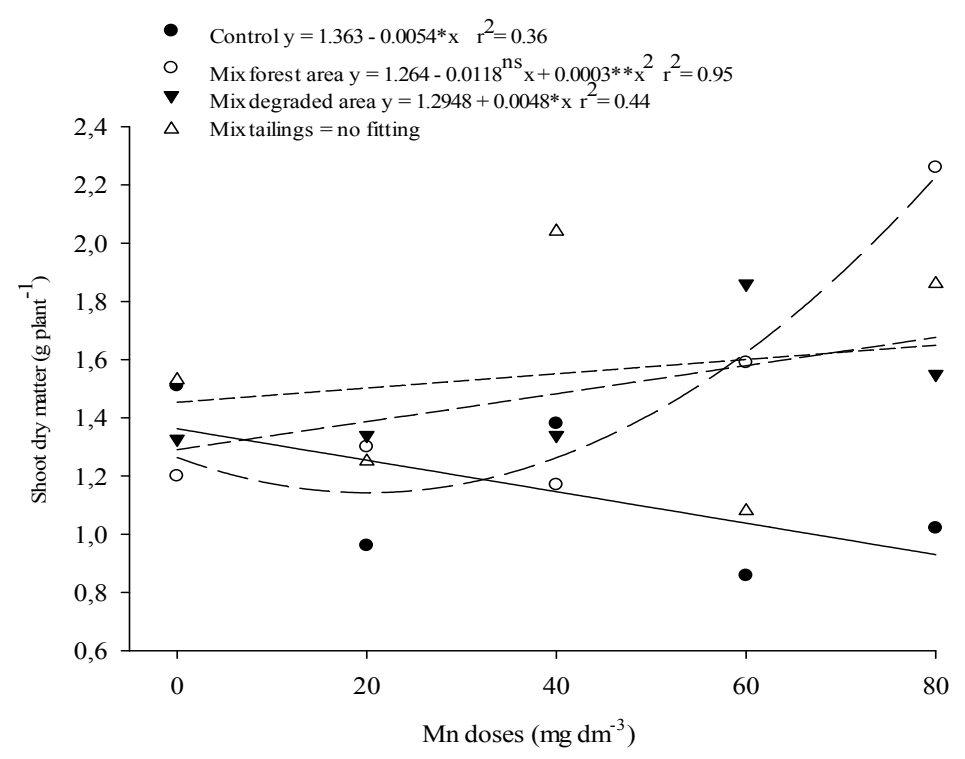

Figure 3. Shoot dry matter (SDM) of sabiá (Mimosa caesalpiniaefolia Benth.) plants subjected to doses of manganese and treatments of inoculation with rhizobia

Strains native to the soil were sensitive to the presence of $\mathrm{Mn}$ at the highest concentrations in the soil, evidenced by the negative effect on shoot dry matter production, whereas rhizobium isolates from Mn-mining area were tolerant to the presence of the metal at the concentrations tested in the present study. As mentioned by Ferreira et al. (2012), the tolerance of $\mathrm{N}_{2}$-fixing bacteria to heavy metals may be related to the origin of the isolates, even when they belong to the same genus or same species. As observed here, the isolates which composed the mixes were obtained from areas with high Mn concentrations, unlike the strains native to the soil used as substrate (control treatment), different from the area contaminated by $\mathrm{Mn}$, which under this experimental condition are similar to what was mentioned by these authors, although one should not generalize such model of behavior.

It is known that one of the mechanisms through which rhizobia can improve the growth of leguminous species in stressing environments is the production of phytohormones such as auxins (indoleacetic acid-IAA). This hormone acts directly on cell division and elongation, thus improving plant growth (Brígido \& Glick, 2015). Hence, it is possible to suppose that the rhizobium isolates from Mn-mining area had higher capacity to produce phytohormones which promote plant growth, compared to the strains native to the natural soil used in the experiment.

According to research studies, sabiá has specificity in the symbiosis with rhizobia, demonstrating to be preferentially nodulated by strains of the genus Burkholderia (Chen et al., 2008a). This group of bacteria is well characterized as plant-growth promoter through solubilization of phosphates, production of phytohormones (auxins, gibberellins and cytokinin) and through symbiotic $\mathrm{N}_{2}$ fixation (Bontemps et al., 2010; Chen et al., 2003; Martins et al., 2015).

Regarding the nitrogen content in the shoots, the control treatment was statistically different from the others, showing the lowest $\mathrm{N}$ content. The isolates from mining area were statistically similar and did not differ from one another. $\mathrm{N}$ accumulation followed the same behavior of $\mathrm{N}$ content, with difference between the isolates from mining area and the control treatment, besides similarity between the different mixes (Table 7).

Table 7. Nitrogen contents (N) and accumulation in the shoots (NAS) of sabiá (Mimosa caesalpiniaefolia Benth.) plants subjected to treatments of inoculation with rhizobia

\begin{tabular}{lll}
\hline Inoculation treatments & $\mathrm{N}\left(\mathrm{g} \mathrm{kg}^{-1}\right)$ & NAS $\left(\mathrm{mg} \mathrm{plant}^{-1}\right)$ \\
\hline Control & $15.31 \mathrm{~b}$ & $18.91 \mathrm{~b}$ \\
Mix Forest area & $22.00 \mathrm{a}$ & $35.31 \mathrm{a}$ \\
Mix Degraded area & $22.49 \mathrm{a}$ & $35.75 \mathrm{a}$ \\
Mix Tailings & $22.59 \mathrm{a}$ & $35.68 \mathrm{a}$ \\
\hline
\end{tabular}

Note. Means followed by the same letters do not differ by Tukey test at 0.01 probability level. 
All plants benefited from the symbiotic $\mathrm{N}_{2}$ fixation by their microsymbionts because there were no symptoms of deficiency of this element until 60 days, and no other source was used. Rhizobium isolates from mining area were more efficient in terms of fixation and, consequently, supply of $\mathrm{N}$ to plants. By comparing the isolates from the mix tailings to the community native to the soil (control), it is possible to note that there was an increment of about $47.0 \%$ in the $\mathrm{N}$ content in the shoots of inoculated plants. Despite the inferiority in $\mathrm{N}$ content and accumulation in plants by the rhizobium community native to the soil, one should take into account that, even with lower production of nodules (at most 3 nodules per plant) (Figure 1), these native strains were able to supply a considerable quantity of $\mathrm{N}$ to plants.

Malavolta, Vitti, and Oliveira (1997) suggest that adequate $\mathrm{N}$ contents for forest species should range from 16 to $35 \mathrm{~g} \mathrm{~kg}^{-1}$, values found in all plants of the present experiment. Ferreira et al. (2013), evaluating the effect of heavy metals on the symbiosis of Mimosa caesalpiniaefolia and strains of Cupriavidus necator, detected $\mathrm{N}$ contents in the shoots from 32 to $39 \mathrm{~g} \mathrm{~kg}^{-1}$. Similar results were also obtained by Ferreira et al. (2012), studying the symbiotic efficiency of the same association, with $\mathrm{N}$ contents in the plant ranging from 11.0 to $36.5 \mathrm{~g} \mathrm{~kg}^{-1}$ and maximum N accumulation of approximately $6 \mathrm{mg}$ plant $^{-1}$.

Based on the analysis of the interaction between doses and NNFB for Mn content in the shoots, there was significant statistical difference for the treatments of inoculation with mix forest area, mix degraded area and mix tailings. The control treatment did not fit to any mathematical model (Figure 4).

The data of the treatment mix forest area fitted to a quadratic regression model, in which the minimum Mn content $\left(6.97 \mathrm{mg} \mathrm{kg}^{-1}\right)$ was obtained at the dose $39.4 \mathrm{mg} \mathrm{dm}^{-3}$. The data of the mix degraded area fitted to a linear regression model, and $\mathrm{Mn}$ content in the shoots decreased with the increasing levels of $\mathrm{Mn}$ in the soil. The data of the mix tailings fitted to a quadratic model in which the minimum Mn content $\left(9.55 \mathrm{mg} \mathrm{kg}^{-1}\right)$ was obtained at $\mathrm{Mn}$ dose of $61.20 \mathrm{mg} \mathrm{dm}^{-3}$ (Figure 4).

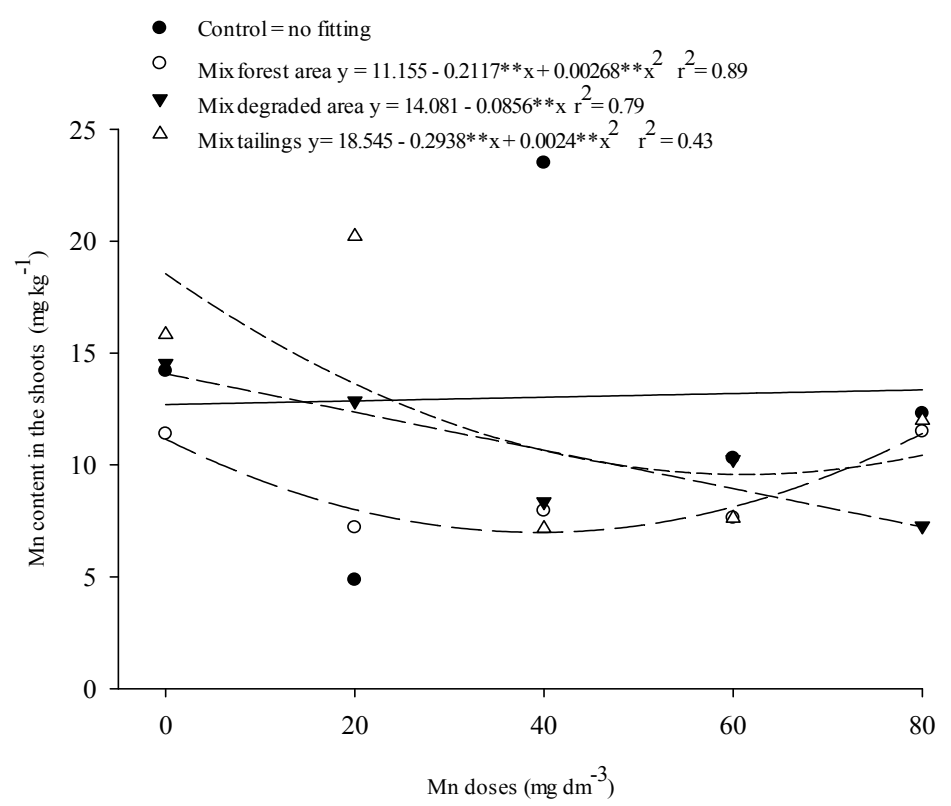

Figure 4. Manganese content in the shoots of sabiá (Mimosa caesalpiniaefolia Benth.) plants subjected to doses of manganese and treatments of inoculation with NNFB

In general, the treatments of inoculation with the rhizobium isolates had influence on $\mathrm{Mn}$ content in the shoots, which decreased as the Mn levels in the soil increased. Chen et al. (2008b) observed an increase in the absorption of $\mathrm{Pb}, \mathrm{Cu}$ and $\mathrm{Cd}$ in Mimosa pudica plants inoculated with Cupriavidus taiwanensis, compared to non-inoculated plants. Wani and Khan (2013), studying the association of the rhizobium strain RL9 with lentil plants, observed reduction in $\mathrm{Ni}$ absorption compared to non-inoculated plants.

According to Brígido and Glick (2015), one of the ways to reduce the absorption of metals by plants inoculated with rhizobia would be the accumulation of metals in root nodules by the strains which nodulate their hosts, while free strains that remain in the rhizosphere perform detoxification by different mechanisms, such as release of 
exopolysaccharides that can bind to various metals, including $\mathrm{Mn}^{2+}$, thus allowing them to be used in the phytostabilization of these metals. Another way to explain the reduction in Mn content in the shoots would be the plant-growth promotion stimulated by bacteria, increasing shoot biomass production and thus inducing an effect of dilution of the element in plant tissue (Zanão Júnior, Fontes, Ávila, \& Korndörfer, 2010).

\section{Conclusions}

All rhizobium isolates from areas degraded by Mn-mining are able to induce the formation of root nodules and fix nitrogen in sabiá (Mimosa caesalpiniaefolia Benth.).

Both the isolates from the area degraded by Mn-mining and the strains native to the substrate used are tolerant to the presence of $\mathrm{Mn}$ at the studied concentrations.

The isolates from the area degraded by Mn-mining, in symbiosis with sabiá, are able to increase the tolerance of this species to excess $\mathrm{Mn}$ in the soil, through a symbiosis that is effective and efficient in $\mathrm{N}_{2}$ fixation, promoting plant growth.

\section{References}

Aafi, N. E., Saidi, N., Maltouf, A. F., Perez-Palacios, P., Dary, M., Brhada, F., \& Pajuelo, E. (2015). Prospecting metal-tolerant rhizobia for phytoremediation of mining soils from Morocco using Anthyllis vulneraria L. Environmental Science and Pollution Research, 22(6), 4500-4512. https://doi.org/10.1007/s11356-0143596-y

Abdu, N., Abdullahi, A. A., \& Abdulkadir, A. (2017). Heavy metals and soil microbes. Environmental Chemistry Letters, 15(1), 65-84. https://doi.org/10.1007/s10311-016-0587-X

Ali, H., Khan, E., \& Sajad, M. A. (2013). Phytoremediation of heavy metals-Concepts and applications. Chemosphere, 91(7), 869-881. https://doi.org/10.1016/j.chemosphere.2013.01.075

Amara, D. S., Mohjadi, W. A., \& Miller, R. H. (1986). Tolerance of Rhizobium phaseoli to acidity, aluminium and manganese. MIRCEN Journal of Applied Microbiology and Biotechnology, 2(2), 289-299. https://doi.org/10.1007/BF00933495

Baker, A. J. M., Ernst, W. H. O., Ent, A. Van Der, Malaisse, F., \& Ginocchio, R. (2010). Metallophytes: The unique biological resource, its ecology and conservational status in Europe, central Africa and Latin America. In L. C. Batty, \& K. B. Hallberg (Eds.), Ecology of Industrial Pollution (1st ed., pp. 7-40). Cambridge: Cambridge University Press. https://doi.org/10.1017/CBO9780511805561.003

Bontemps, C., Elliott, G. N., Simon, M. F., Dos Reis Júnior, F. B., Gross, E., Lawton, R. C., ... Young, J. P. W. (2010). Burkholderia species are ancient symbionts of legumes. Molecular Ecology, 19(1), 44-52. https://doi.org/10.1111/j.1365-294X.2009.04458.x

Brenner, D. J., Krieg, N. R., \& Staley, J. T. (2005). Part C The Alpha-, Beta-, Delta-, and Epsilonproteobacteria. In D. J. Brenner, N. R. Krieg, \& J. T. Staley (Eds.), Bergey's Manual of Systematic Bacteriology: The Proteobacteria (2nd ed.). East Lansing: Springer.

Brígido, C., \& Glick, B. R. (2015). Phytoremediation Using Rhizobia. In A. A. Ansari, S. S. Gill, R. Gill, G. R. Lanza, \& L. Newman (Eds.), Phytoremediation: Management of Environmental Contaminants (1st ed., p. 366). Springer.

Carvalho, P. E. R. (2007). Sabiá Mimosa caesalpiniifolia. Colombo, PR: Embrapa Florestas.

Castro, J. L. de, Souza, M. G., Rufini, M., Guimarães, A. A., Rodrigues, T. L., \& Moreira, F. M. de S. (2017). Diversity and efficiency of rhizobia communities from iron mining areas using cowpea as a trap plant. Revista Brasileira de Ciencia do Solo, 41, 1-20. https://doi.org/10.1590/18069657rbcs20160525

Chen, W.-M., Moulin, L., Bontemps, C., Vandamme, P., Béna, G., \& Boivin-Masson, C. (2003). Legume symbiotic nitrogen fixation by beta-proteobacteria is widespread in nature. Journal of Bacteriology, 185(24), 7266-72. https://doi.org/10.1128/JB.185.24.7266-7272.2003

Chen, W. M., de Farja, S. M., Chou, J. H., James, E. K., Elliott, G. N., Sprent, J. I., ... Vandamme, P. (2008a). Burkholderia sabiae sp. nov., isolated from root nodules of Mimosa caesalpiniifolia. International Journal of Systematic and Evolutionary Microbiology, 58(9), 2174-2179. https://doi.org/10.1099/ijs.0.65816-0

Chen, W. M., Wu, C. H., James, E. K., \& Chang, J. S. (2008b). Metal biosorption capability of Cupriavidus taiwanensis and its effects on heavy metal removal by nodulated Mimosa pudica. Journal of Hazardous Materials, 151(2-3), 364-371. https://doi.org/10.1016/j.jhazmat.2007.05.082 
Cubillas, C., Vinuesa, P., Luisa Tabche, M., Dávalos, A., Vázquez, A., Hernández-Lucas, I., ... García-de los Santos, A. (2014). The cation diffusion facilitator protein EmfA of Rhizobium etli belongs to a novel subfamily of $\mathrm{Mn}^{2+} / \mathrm{Fe}^{2+}$ transporters conserved in $\alpha$-proteobacteria. Metallomics, 6(10), 1808-1815. https://doi.org/10.1039/C4MT00135D

Dionísio, J. A., Pimentel, I. C., Signor, D., Paula, A. M., Maceda, A., \& Mattana, A. L. (2016). Guia prático de Biologia do solo (1st ed.). Paraná: Sociedade Brasileira de Ciências do Solo.

Dobereiner, J. (1966). Manganese toxicity effects on nodulation and nitrogen fixation of beans (Phaseolus vulgaris L.), in acid soils. Plant and Soil, 24(1), 153-166. https://doi.org/10.1007/BF01373081

EMBRAPA. (2017). In P. C. Teixeira, G. K. Donagemma, A. Fontana, \& W. G. Teixeira (Eds.), Manual de métodos de análises de solos (3rd ed.). Rio de Janeiro: Embrapa Solos.

Ferreira, D. F. (2011). Sisvar: A computer statistical analysis system. Ciencia e Agrotecnologia, 35(6), 1039-1042. https://doi.org/10.1590/S1413-70542011000600001

Ferreira, P. A. A., Bomfeti, C. A., Silva Júnior, R. da, Soares, B. L., Soares, C. R. F. S., \& Moreira, F. M. de S. (2012). Eficiência simbiótica de estirpes de Cupriavidus necator tolerantes a zinco, cádmio, cobre e chumbo. Pesquisa Agropecuaria Brasileira, 47(1), 85-95. https://doi.org/10.1590/S0100-204X20120001 00012

Ferreira, P. A. A., Lopes, G., Bomfeti, C. A., Longatti, S. M. de O., Soares, C. R. F. de S., Guilherme, L. R. G., \& Moreira, F. M. de S. (2013). Leguminous plants nodulated by selected strains of Cupriavidus necator grow in heavy metal contaminated soils amended with calcium silicate. World Journal of Microbiology and Biotechnology, 29(11), 2055-2066. https://doi.org/10.1007/s11274-013-1369-2

Foy, C. D. (1983). Plant adaptation to mineral stress in problem soils. Iowa State Journal of Research., 57, 339-354.

Franco, A. A., \& Dôbereiner, J. (1971). Toxidez de manganës de um solo ácido na simbiose soja—Rhizobium. Pesquisa Agropecuaria Brasileira, 6, 57-66.

Gerdemann, J. W., \& Nicolson, T. H. (1963). Spores of mycorrhizal Endogone species extracted from soil by wet sieving and decanting. Transactions of the British Mycological Society, 46(2), 235-244. https://doi.org/ 10.1016/ S0007-1536(63)80079-0

Glick, B. R. (2010). Using soil bacteria to facilitate phytoremediation. Biotechnology Advances, 28(3), $367-374$. https://doi.org/10.1016/j.biotechadv.2010.02.001

Grison, C. M., Jackson, S., Merlot, S., Dobson, A., \& Grison, C. (2015). Rhizobium metallidurans sp. nov., a symbiotic heavy metal resistant bacterium isolated from the Anthyllis vulneraria Zn-hyperaccumulator. International Journal of Systematic and Evolutionary Microbiology, 65(5), 1525-1530. https://doi.org/ 10.1099/ijs.0.000130

Hoagland, D. R., \& Arnon, D. I. (1950). The water-culture method for growing plants without soil. California Agricultural Experiment Station Circular (Vol. 347). California, USA.

Hungria, M., \& Araujo, R. S. (1994). Manual de métodos empregados em estudos de microbiologia agrícola (1st ed.). Brasilia, DF: Embrapa.

Kabata-Pendias, A. (2011). Trace elements in soils and plants (4th ed.). Nova York: Taylor \& Francis Group.

Köppen, W. (1931). Grundriss der Klimakunde. Berlin: Walter de Gruyter.

Lima, P. C. F., Lima, A. Q., \& Drumond, M. A. (2003). Choice of species for recovering a degraded mining area in the semiarid zone of Brasil. In R. Lemons, J. Victor, \& D. Schaffe (Eds.), Conserving Biodiversity in Arid Regions: Best Practices in Developing Nations (p. 493). New York: Springer. https://doi.org/10.1007/ 978-1-4615-0375-0 21

Malavolta, E., Vitti, G. C., \& Oliveira, S. (1997). Avaliação do estado nutricional das plantas: Princípios e aplicações (2nd ed.). Piracicaba: POTAFOS.

Martins, P. G. S., Junior, M. A. L., Fracetto, G. G. M., da Silva, M. L. R. B., Vincentin, R. P., \& de Lyra, M. do C. C. P. (2015). Mimosa caesalpiniifolia rhizobial isolates from different origins of the Brazilian Northeast. Archives of Microbiology, 197(3), 459-469. http://doi.org/10.1007/s00203-014-1078-8

Martins, L. M. V, Neves, M. C. P., \& Rumjanek, N. G. (1997). Growth characteristics and symbiotic efficiency of rhizobia isolated from cowpea nodules of the north-east region of Brazil. Soil Biology and Biochemistry, 
29(5-6), 1005-1010. http://doi.org/10.1016/S0038-0717(96)00215-5

Matsuda, A., Moreira, F. M. D. S., \& Siqueira, J. O. (2002). Tolerância de rizóbios de diferentes procedências ao zinco, cobre e cádmio. Pesquisa Agropecuaria Brasileira, 37(3), 343-355. https://doi.org/10.1590/S0100204X2002000300016

Nocelli, N., Bogino, P. C., Banchio, E., \& Giordano, W. (2016). Roles of extracellular polysaccharides and biofilm formation in heavy metal resistance of rhizobia. Materials, 9(6), 1-19. https://doi.org/10.339 $0 /$ ma9060418

Nonnoi, F., Chinnaswamy, A., García de la Torre, V. S., Coba de la Peña, T., Lucas, M. M., \& Pueyo, J. J. (2012). Metal tolerance of rhizobial strains isolated from nodules of herbaceous legumes (Medicago spp. and Trifolium spp.) growing in mercury-contaminated soils. Applied Soil Ecology, 61, 49-59. https://doi.org/10.1016/j.apsoil.2012.06.004

Rangel, W. M., Thijs, S., Janssen, J., Longatti, S. M. O., Bonaldi, D. S., Ribeiro, P. R. A., ... Moreira, F. M. S. (2017). Native rhizobia from $\mathrm{Zn}$ mining soil promote the growth of Leucaena leucocephala on contaminated soil. International Journal of Phytoremediation, 19(2), 142-156. https://doi.org/10.1080/1522 6514.2016 .1207600

Rashed, M. N. (2010). Monitoring of contaminated toxic and heavy metals, from mine tailings through age accumulation, in soil and some wild plants at Southeast Egypt. Journal of Hazardous Materials, 178(1-3), 739-746.

Schalk, I. J., Hannauer, M., \& Braud, A. (2011). New roles for bacterial siderophores in metal transport and tolerance. Environmental Microbiology, 13(11), 2844-2854.

Silva, F. C. da. (2009). Manual de análises químicas de solos, plantas e fertilizantes (2nd ed.). Brasilia, DF: Embrapa Informação Tecnológica.

Sprent, J. I. (1994). Evolution and diversity in the legume-Rhizobium symbiosis: Chaos theory? Plant and Soil, 161(1), 1-10. http://doi.org/10.1007/BF02183080

Tedesco, M. J., Bohnem, H., Gianello, C., Bissani, C. A., \& Volkweiss, S. J. (1995). Análise de solo, plantas e outros materiais (Boletin Técnico, 5, 2nd ed.). Porto Alegre: Universidade Federal do Rio Grande do Sul.

Trannin, I. C. B., Moreira, F. M. S., \& Siqueira, J. O. (2001). Crescimento e nodulação de Acacia mangium, Enterolobium contortisiliqqum e Sesbania virgata em solo contaminado com metais pesados. Revista Brasileira de Ciência Do Solo, 25(3), 743-753. https://doi.org/10.1590/S0100-06832001000300024

Trannin, I. C. B., Moreira, F. M. S., Siqueira, J. O., \& Lima, A. (2001). Tolerância de estirpes e isolados de Bradyrhizobium e de Azorhizobium a zinco, cádmio e cobre "in vitro". Revista Brasileira de Ciência Do Solo, 25(2), 305-316. https://doi.org/10.1590/S0100-06832001000200007

Vincent, J. M. (1970). A manual for the practical study of rooot-nodule bacteria. International Biological Programme Handbook (1st ed.). Londres: Blackwell Scientific Publications.

Wani, P. A., \& Khan, M. S. (2013). Nickel detoxification and plant growth promotion by multi metal resistant plant growth promoting Rhizobium species RL9. Bulletin of Environmental Contamination and Toxicology, 91(1), 117-124. https://doi.org/10.1007/s00128-013-1002-y

Wei, Y., Hou, H., ShangGuan, Y., Li, J., \& Li, F. (2014). Genetic diversity of endophytic bacteria of the manganese-hyperaccumulating plant Phytolacca americana growing at a manganese mine. European Journal of Soil Biology, 62, 15-21. https://doi.org/10.1016/j.ejsobi.2014.02.011

Zanão Júnior, L. A., Fontes, R. L. F., Ávila, V. T. de, \& Korndörfer, G. H. (2010). Absorção de cálcio e ferro por arroz cultivado em solução nutritiva com doses de silício e manganês. Scientia, 11(3), 263-269.

\section{Copyrights}

Copyright for this article is retained by the author(s), with first publication rights granted to the journal.

This is an open-access article distributed under the terms and conditions of the Creative Commons Attribution license (http://creativecommons.org/licenses/by/4.0/). 